\title{
PERLINDUNGAN ANAK YANG DITANGKAP OLEH MILITER ASING DI NEGARA KONFLIK
}

\author{
Faisal Riza \\ Fakultas Hukum Universitas Muhammadiyah Sumatera Utara \\ Email: faisalrizaadv@gmail.com
}

\begin{abstract}
The presence of children in armed conflict is not a rare case and cannot be avoided. Therefore, the protection of children is needed because of the age of them are still young and need a care, protection, and affection more than families and people who are nearby. A child who was captured by a foreign army in a conflict country, a reality that is bitter and depressing. Children are part of the civilian population must be protected, as stated in Article 24 of Geneva Convention IV which ensures that the warring factions will take the necessary actions for children under fifteen years old, children orphaned separate from his family because of the war, would not be left alone. These children get the protection, maintenance, and assistance in the implementation of worship and education. This convention ensures that children will remain protected in armed conflicts. The results showed that children who carried out the arrest of foreign military in armed conflict is a war crime that should not be done, because the children were arrested will undergo traumatic and it took a long time to recover.
\end{abstract}

\section{Kata Kunci: Perlindungan Anak, Militer Asing, Negara Konflik}

\section{A. Latar Belakang}

Konflik bersenjata (armed conflict) suatu keadaan yang tidak asing lagi di dunia Internasional. Kurun waktu sekitar 74 tahun belakangan ini setelah munculnya Konvensi-konvensi Jenewa 1949, hampir seluruh manusia mengalami konflik bersenjata dengan jumlah yang sangat besar. Konflik bersenjata cenderung menimbulkan kekacauan, kehancuran dan kesengsaraan pada kehidupan manusia, baik terhadap kombatan maupun non-kombatan.

Kombatan dan penduduk sipil dalam hukum humaniter Internasional harus dibedakan. Meskipun pembedaan terhadap kombatan dengan penduduk sipil hal yang penting, namun perlindungan terhadap keduanya juga tidak kalah penting. Baik kombatan maupun penduduk sipil tetap mendapatkan perlindungan sesuai dengan Hukum Humaniter Internasional. Sesungguhnya perlindungan terhadap 
kombatan telah diatur dalam Konvensi Jenewa III (The Geneva Convention relative to the Treatment of Prisoners of War), sedangkan perlindungan terhadap penduduk sipil diatur dalam Konvensi Jenewa IV (The Geneva Convention relative to the Protection of Civilian Persons in Time of War).

Khusus bagi anak-anak, Pasal 24 Konvensi Jenewa IV menjamin bahwa pihak yang bertikai akan mengambil tindakan yang diperlukan untuk anak-anak di bawah lima belas tahun, anak-anak yatim piatu yang terpisah dari keluarganya karena perang, tidak akan dibiarkan sendiri. Anak-anak tersebut akan mendapatkan perlindungan, pemeliharaan, dan bantuan dalam pelaksanaan ibadah dan pendidikan.

Pihak-pihak yang bertikai harus membantu usaha penempatan anak-anak di negara netral dan harus mengambil tindakan-tindakan yang perlu agar semua anak di bawah 12 tahun diberi tanda-tanda identitet (cakram pengenal dan sebagainya). Keterangan mengenai identitas, harus diberikan kepada pihak penawan. Setiap pihak dalam sengketa harus melengkapi setiap orang yang mungkin menjadi tawanan perang musuh dengan suatu kartu pengenal (identitas) (Mochtar Kusumaatmadja 2002: 77). Bukan justru ditangkap untuk dimanfaatkan, disakiti bahkan dibunuh.

Perlakuan khusus terhadap anak-anak juga diatur dalam Pasal 77 Protokol I. Menurut Protokol I, anak-anak berhak atas perawatan dan bantuan yang dibutuhkan sesuai dengan usia mereka, mereka tidak boleh didaftarkan menjadi anggota angkatan perang sebelum berusia 15 tahun, dan jika sebelum usia tersebut mereka terlibat langsung dalam pertempuran, maka apabila tertangkap, mereka harus menerima perlakuan khusus sesuai dengan usia mereka, dan terhadap mereka yang tertangkap sebelum usia 18 tahun tidak boleh dijatuhi hukuman mati.

Perlindungan terhadap anak-anak di tengah konflik bersenjata juga diatur dalam Convention on the Rights of the Child dan Optional Protocol to the Convention on the Rights of the Child on the involvement of children in armed conflict. Pasal 8 Declaration of the Rights of the Child menyatakan bahwa: "The child shall in all circumstances be among the first to receive protection and relief." Hal ini berarti, anak adalah prioritas utama, Anak harus mendapatkan 
perlindungan dan bantuan. Hal ini tetap berlaku terhadap anak-anak yang hidup dan tinggal di tengah konflik bersenjata, bahwa anak-anak tersebut menjadi prioritas untuk mendapatkan perlindungan dan bantuan.

Meskipun anak-anak telah diberi perlindungan agar tetap menjalankan hidupnya dengan baik meskipun di tengah konflik bersenjata seperti di Afganistan, Suriah dan wilayah konflik lainnya, namun pada nyatanya masih banyak anak-anak yang menjadi korban dan tidak mendapatkan perlindungan secara penuh, oleh karena itu, berbagai permasalahan anak di negara konflik perlu dilakukan kajian dan penelitian untuk dicari solusinya.

\section{B. Metode Penelitian}

Penelitian ini bersifat deskriptif analisis yaitu menggambarkan dan memaparkan secara sistematis tentang objek penelitian yaitu mengenai hal-hal yang berhubungan dengan perlindungan bagi anak yang ditangkap di negara konflik dan kemudian dilakukan suatu analisa dengan menggunakan berbagai konsep dan teori yang sesuai dengan sumber data dan objek penelitian. Adapun metode pendekatan yang digunakan untuk melakukan penelitian ini adalah metode pendekatan hukum normatif (yuridis normatif).

Sumber data dalam penelitian ini diperoleh (bersumber) dari data sekunder. Secara umum, dalam penelitian biasanya dibedakan antara data yang diperoleh secara langsung dari masyarakat dan dari bahan pustaka. Data yang diperoleh langsung adalah data primer dan yang kedua disebut data sekunder. Data sekunder terdiri dari:

1. Bahan hukum primer, yaitu Konvensi Jenewa III, Konvensi Jenewa IV, Konvensi Jenewa 1949 dan Protokol Tambahan I dan II Tahun 1977 maupun dalam lingkup hukum internasional yang lain, seperti Konvensi Hak Anak dan Protokol Tambahannya, Statuta ICC dan juga Konvensi ILO.

2. Bahan hukum sekunder yaitu bahan hukum yang memperjelas bahan hukum primer yaitu buku, tulisan ilmiah yang ada dalam jurnal/artikel ilmiah, majalah, koran. 
3. Bahan hukum tersier atau bahan hukum pelengkap yaitu terdiri dari kamus umum, kamus hukum, ensiklopedia data, bahan dari internet.

Alat pengumpulan data mana yang akan dipergunakan di dalam suatu penelitian hukum, senantiasa tergantung pada ruang lingkup dan tujuan penelitian hukum yang akan dilakukan. Alat pengumpul data yang digunakan dalam penelitian ini adalah studi kepustakaan (library research).

Sifat penelitian ini adalah deskriptif, yang bertujuan untuk memberikan gambaran tentang gejala-gejala sosial yang terkait dengan problematika penyusunan peraturan daerah. Sumber data penelitian berupa bahan hukum primer, bahan hukum sekunder dan bahan hukum tersier. Metode pengumpulan data dilakukan menggunakan teknik studi dokumen, yang dianalisis dengan menggunakan teknik analisis kualitatif.

Data-data yang diperoleh dalam penelitian ini dianalisis dengan cara analisis kualitatif, yaitu suatu kegiatan yang mana suatu data yang diperoleh, diedit terlebih dahulu, untuk selanjutnya dimanfaatkan sebagai bahan analisa yang sifatnya kualitatif.

\section{Hasil Penelitian dan Analisis}

\section{Pengaturan hukum perlindungan anak menurut hukum internasional}

Sejak Tahun 1924 ketika Deklarasi tentang Hak-hak Anak Internasional yang pertama diadopsi oleh Liga Bangsa-Bangsa, anak memiliki hak-hak untuk diakui dalam hukum Internasional. Deklarasi Universal Hak-hak Asasi Manusia Tahun 1948 dan Deklarasi Amerika tentang hak-hak dan kewajiban manusia mengakui secara lebih umum hak manusia untuk bebas dari kekerasan, abuse, dan ekploitasi. Hak-hak ini berlaku bagi setiap orang, termasuk anak-anak, dan dikembangkan lebih jauh dalam instrumen-instrumen seperti Kovensi Internasional tentang Hak-hak Politik dan Hak-hak Sipil 1966 (Lovetya, http:// lovetya.wordpress.com.)

Pada Tahun 1989, Konvensi Perserikatan Bangsa-Bangsa tentang HakHak Anak diadopsi oleh Sidang Majelis Umum. Konvensi ini dengan cepat menjadi perjanjian hak-hak azasi manusia yang paling luas diratifikasi dalam 
sejarah, diratifikasi hampir secara universal. Konvensi Hak-hak Anak, dalam beberapa hal meningkatkan standar Internasional mengenai hak-hak anak.

\section{a. Konvensi hak anak (committee on the rights of the child 1989)}

Aturan mengenai perekrutan tentara anak juga terdapat dalam International Convention on the Right of the Child (Konvensi Hak Anak) yang ditandatangani pada 20 Nopember 1989, dan mulai berlaku sejak 2 September 1990. Ketentuan hukum yang mengatur mengenai keterlibatan anak dalam konflik bersenjata hanya terdapat dalam satu pasal saja, yaitu Pasal 38 yang memuat berbagai kewajiban negara untuk tidak merekrut anak di bawah usia 15 tahun dan memberikan perlindungan bagi anak yang terkena dampak konflik bersenjata. Pasal tersebut tidak memberikan pengaturan yang baru dalam hal pelibatan anak dalam konflik bersenjata, tetapi hanya merupakan pengulangan dari Pasal 77 ayat (2) Protokol Tambahan I Tahun 1977. Konvensi ini hanya melarang partisipasi langsung anak di bawah 15 tahun dalam suatu permusuhan (Enny Narwati dan Lina Hastuti 2008).

Pengaturan ini lebih longgar jika dibandingkan dengan Hukum Humaniter yang mengatur tentang konflik bersenjata non-internasional, yang dengan tegas melarang partisipasi anak baik langsung maupun tidak langsung dalam permusuhan. Tetapi, Pasal 38 ayat (1) merujuk kepada Hukum Humaniter Internasional yang relevan tentang perlindungan kepada anak-anak, oleh karena itu apabila terdapat keraguan hukum mana yang akan diterapkan dalam suatu situasi, maka berdasarkan asas lex specialis yang berlaku adalah Hukum Humaniter Internasional.

Terdapat empat prinsip umum untuk membentuk interpretasi atas konvensi tersebut secara keseluruhan yaitu:

1) Non-diskriminasi (Pasal 2);

2) Kepentingan terbaik bagi anak (Pasal 3);

3) Hak untuk hidup, kelangsungan hidup dan mengembangkan diri (Pasal 6);

4) Pandangan anak (Pasal 12).

Anak-anak harus dibebaskan untuk mempunyai pendapat tentang semua hal yang bersangkutan dengan diri mereka, dan pandangan ini harus diperhatikan 
sesuai dengan usia dan kematangan si anak. Ide yang mendasar adalah bahwa anak-anak mempunyai hak untuk didengar dan hak agar pendapatnya diperhatikan dengan serius, termasuk prosedur hukum atau administratif yang bersangkutan dengan diri mereka.

\section{b. Protokol tambahan konvensi hak anak (2000)}

Konvensi Hak Anak 1989 dilengkapi dengan Optional Protocol on the Involvement in Armed Conflict to the Convention on the Right of the Child atau disebut dengan Protokol Tambahan Tahun 2000, yang ditandatangani pada tanggal 25 Mei 2000. Protokol ini berisi 13 pasal, dan sesuai dengan namanya, protokol ini khusus berlaku bagi anak-anak yang terlibat dalam konflik bersenjata. Protokol ini juga melengkapi dan memperjelas norma yang mengatur tentang pelibatan anak dalam konflik bersenjata (Enny Narwati dan Lina Hastuti 2008: 5).

Di antara ketiga belas pasal yang penting untuk dibicarakan adalah Pasal 1, 2 3, 4 dan 6. Pasal-pasal tersebut mengatur tentang kewajiban negara untuk memastikan bahwa anak-anak yang berusia 18 tahun tidak terlibatan secara langsung dalam suatu permusuhan. Protokol ini juga meletakkan kewajiban kepada negara peserta untuk tidak merekrut secara wajib orang-orang yang belum mencapai usia 18 tahun ke dalam angkatan bersenjata mereka. Ketentuan ini merupakan perbaikan dari Konvensi Hak Anak 1989 yang menyatakan bahwa batas usia minimum anak untuk dapat direkrut adalah 15 tahun.

Mengenai rekrutment secara sukarela, negara peserta terikat dengan usia minimum ini. Ketentuan selanjutnya mengatakan bahwa rekrutment tersebut telah mendapatkan persetujuan dari orang tua atau walinya. Tetapi, yang perlu mendapat perhatian adalah pengaturan tentang rekrutment sukarela tersebut tidak berlaku dikalangan akademi militer. Larangan ini tidak hanya berlaku bagi angkatan bersenjata negara peserta saja, tetapi juga berlaku bagi kelompokkelompok bersenjata yang lain dan juga berlaku dalam segala situasi (Enny Narwati dan Lina Hastuti 2008: 5).

Pasal 6 mengatur tentang kewajiban negara peserta untuk memastikan bahwa ketentuan-ketentuan dalam Protokol ini dilaksanakan secara efektif dan mempunyai kekuatan mengikat di bawah yurisdiksinya. Negara juga diwajibkan 
untuk memberikan semua bantuan yang tepat untuk pemulihan fisik dan psikologis serta penyatuan kembali kehidupan sosial anak-anak yang telah direkrut dan terlibat dalam permusuhan.

Pengakuan hak anak atas perlindungan tidak hanya terbatas pada Konvensi hak-hak Anak. Ada sejumlah instrumen, baik instrumen Perserikatan BangsaBangsa maupun instrumen dari badan internasional lainnya, yang juga memasukkan hak-hak ini. Instrumen-instrumen itu meliputi (Lovetya, http:// lovetya.wordpress.com.):

1) Piagam Afrika tentang Hak-hak dan Kesejahteraan Anak, Organisasi Persatuan Afrika yang sekarang disebut Uni Afrika (The African Charter on the Rights and Welfare of the Child of the Organisation for African Unity) Tahun 1993.

2) Konvensi-konvensi Jenewa mengenai Hukum Humaniter Internasional (1949)

Tidak ditemukan dalam Konvensi Jenewa 1949 definisi tentang siapa saja yang dikategorikan sebagai anak. Konvensi Jenewa 1949 hanya mengatur persoalan pemberian perlindungan terhadap anak dari akibat pertempuran. Hal ini bisa dikatakan bahwa Konvensi Jenewa tidak pernah melarang anak untuk ikut secara aktif dalam pertempuran.

Konvensi Jenewa III tentang Perlakuan Tawanan Perang mengatur persoalan yang berkaitan dengan anak hanya dalam 2 (dua) pasal saja, yaitu Pasal 16 dan 49. Ketentuan Pasal 16 ini berkaitan dengan Pasal 4A dari konvensi yang sama, yang mengatur tentang siapa saja yang berhak untuk mendapat status dan dapat diperlakukan sebagai tawanan perang. Apabila orang-orang yang disebutkan dalam Pasal 4A tersebut berusia di bawah 18 tahun maka ketentuan Pasal 16 berlaku terhadapnya (Enny Narwati dan Lina Hastuti 2008: 5).

Pasal 49 Konvensi Jenewa III mengatakan bahwa Negara penahan dapat menggunakan tenaga kerja tawanan perang yang sehat jasmaninya, dengan memperhatikan umur, jenis kelamin, pangkat dan pembawaan jasmani mereka, dan dengan maksud terutama memelihara mereka dalam keadaan jasmani dan rohani yang baik. 
Anak-anak yang berpartisipasi dalam permusuhan tetapi mereka bukan kombatan menjadi tanggung jawab dari negara kewarga-negaraannya. Sekalipun hukuman disiplin boleh diterapkan pada orang-orang yang diinternir, tetapi umur, jenis kelamin dan kondisi kesehatan mereka harus ikut dipertimbangkan dalam penerapan hukuman tersebut. Hukuman yang diterapkan tidak boleh melanggar perikemanusiaan, ganas atau berbahaya bagi kesehatan orang-orang yang diinternir (Enny Narwati dan Lina Hastuti 2008: 4).

Perlindungan hukum yang diberikan kepada anak lebih tertuju pada akibat sengketa bersenjata yang akan menimpa atau berdampak pada anak. Sebagai bagian dari penduduk sipil, anak-anak yang tidak turut serta dalam suatu permusuhan mendapatkan perlindungan umum tanpa perbedaan yang merugikan apapun yang didasarkan atas suku, kewarganegaraan, agama atau pendapat politik, dan dimaksudkan untuk meringankan penderitaan yang disebabkan oleh perang (Enny Narwati dan Lina Hastuti 2008: 6).

Selain penduduk sipil secara umum yang harus mendapatkan perlindungan, terdapat beberapa kategori yang juga perlu mendapatkan perlindungan, yaitu orang asing, termasuk juga anak-anak di wilayah pendudukan. Selain orang asing maka kategori penduduk sipil yang lain adalah mereka yang tinggal di wilayah pendudukan. Kategori terakhir adalah mereka yang termasuk dalam interniran sipil (Enny Narwati dan Lina Hastuti 2008: 6).

Anak-anak yang berada dalam wilayah suatu pihak dalam sengketa, atau dalam wilayah yang diduduki oleh suatu pihak dalam sengketa diperbolehkan mengirimkan kabar yang benar-benar bersifat pribadi kepada anggota-anggota keluarganya, dimanapun keluarga itu berada, dan untuk menerima kabar dari anggota-anggota keluarganya tersebut. Untuk kepentingan itu, para pihak dalam sengketa harus berhubungan dengan suatu perantara netral, seperti Kantor Pusat, dan secara bersama-sama menentukan cara untuk menjamin terlaksana sepenuhnya kewajiban-kewajiban tersebut, terutama dengan bantuan dan Perhimpunan Palang Merah Nasional. Hal ini ditegaskan dalam Pasal 25 Konvensi Jenewa IV bahwa semua orang dalam wilayah suatu pihak dalam sengketa, atau dalam wilayah yang diduduki oleh suatu pihak dalam sengketa 
diperbolehkan mengirimkan kabar yang benar-banar bersifat pribadi kepada anggota-anggota keluarga mereka, di manapun keluarga itu berada, dan untuk menerima kabar dari mereka.

Apabila karena akibat keadaan-keadaan, pertukaran surat-menyurat keluarga dengan perantara pos biasa menjadi sukar, maka pihak-pihak dalam sengketa bersangkutan harus berhubungan dengan suatu perantara netral, seperti Kantor Pusat termasuk dalam Pasal 140, dan akan menentukan bersama-sama dengan kantor pusat itu, cara untuk menjamin sepenuhnya kewajiban-kewajiban mereka dengan sebaik mungkin, terutama dengan bantuan dan perhimpunan Palang Merah Nasional (Bulan Sabit Merah, Singa dan Matahari Merah).

Anak-anak sebagai bagian dari orang-orang yang dilindungi yang berada dalam wilayah para pihak dalam sengketa berhak akan penghormatan atas diri pribadi, kehormatan hak-hak kekeluargaan, keyakinan dan praktek keagamaan, serta adat istiadat dan kebiasaan mereka dalam segala keadaan. Mereka dilarang untuk diperlakukan tanpa perikemanusiaan.

Selain itu, mereka diharuskan pula untuk diberikan perlindungan khusus terhadap segala tindakan kekerasan atau ancaman kekerasan terhadap penghinaan serta tidak boleh menjadi objek tontonan umum. Penegasan tentang hal ini ditetapkan dalam Pasal 27 yang dinyatakan bahwa orang-orang yang dilindungi, dalam segala keadaan berhak akan penghormatan atas diri pribadi, kehormatan hak-hak kekeluargaan, keyakinan dan praktek keagamaan, serta adat istiadat dan kebiasaan mereka harus diperlakukan dengan perikemanusiaan, dan harus dilindungi khusus terhadap segala tindakan kekerasan atau ancaman-ancaman kekerasan terhadap penghinaan serta tidak boleh menjadi objek tontonan umum.

Anak-anak di bawah usia 15 tahun dalam wilayah sengketa ditetapkan harus memperoleh manfaat dari tiap perlakuan istimewa, seperti juga warga Negara yang bersangkutan. Hal ini berbeda dengan orang-orang asing lainnya yang berada dalam wilayah sengketa yang mendapatkan perlakuan sebagaimana layaknya perlakuan terhadap orang asing pada waktu damai. Ketentuan tentang perlakuan terhadap anak-anak di bawah usia lima tahun yang berstatus sebagai orang asing, demikian juga wanita hamil dan ibu-ibu dari anak-anak di bawah 
tujuh tahun diatur dalam Pasal 38 yaitu dengan perkecualian tindakan-tindakan khusus yang dikuasakan oleh Konvensi ini, terutama oleh Pasal 27 dan Pasal 41, maka keadaan orang-orang yang dilindungi pada prinsipnya harus tetap diatur oleh ketentuan-ketentuan mengenai orang-orang asing di waktu damai (Agus Prakoso 2007: 21). Hak-hak berikut harus diberikan kepada mereka:

1) Untuk menerima sumbangan-sumbangan perorangan atau kolektif, yang mungkin dikirim kepada mereka;

2) Memperoleh pengamatan kesehatan dan perawatan rumah sakit yang sama dengan warga negara bersangkutan;

3) Menjalankan ibadahnya dan menerima bantuan rohani dari rohaniawan kepercayaan mereka;

4) Apabila mereka berdiam di suatu daerah yang sangat diancam bahaya peperangan, maka mereka harus diperbolehkan untuk menyingkir dari daerah itu seperti juga warga negara-negara yang bersangkutan;

5) Anak-anak di bawah lima belas tahun, wanita hamil dan ibu-ibu dari anakanak di bawah tujuh tahun akan memperoleh manfaat dari tiap perlakuan istimewa, seperti juga warga negara-negara yang bersangkutan.

Perlindungan terhadap anak-anak sebagai bagian dari orang-orang yang dilindungi berlaku pula dalam wilayah-wilayah yang diduduki ketika suatu sengketa bersenjata terjadi.

\section{c. Protokol tambahan Kovensi Jenewa (1977)}

Protokol Tambahan I Tahun 1977 merupakan sumber Hukum Humaniter utama yang menyesuaikan dengan perkembangan pengertian sengketa bersenjata, pentingnya perlindungan yang lebih lengkap bagi mereka yang luka, sakit dan korban kapal karam dalam suatu peperangan, serta antisipasi terhadap perkembangan mengenai alat dan cara berperang. Protokol tambahan ini menambah dan menyempurnakan isi dari Konvensi Jenewa, tidak menghapus atau meniadakan Konvensi yang mengatur konflik bersenjata (Enny Narwati 2008: 4).

Sebagai salah satu sumber hukum utama, Protokol Tambahan I memuat beberapa ketentuan tentang keterlibatan anak secara langsung dalam suatu konflik bersenjata. Pasal 77 ayat (2) meletakkan kewajiban bagi negara peserta agar tidak 
mengikutsertakan anak-anak yang belum mencapai usia 15 tahun untuk ikut ambil bagian secara langsung dalam permusuhan.

Protokol Tambahan I lebih mengutamakan mereka yang berusia di atas 18 tahun, dan apabila mereka melakukan suatu pelanggaran dalam hubungannya dengan permusuhan tersebut, maka hukuman mati hanya boleh dijatuhkan bagi mereka yang telah mencapai usia 18 tahun pada saat pelanggaran itu dilakukan.

Anak-anak yang belum mencapai usia 15 tahun harus ikut terlibat secara langsung dalam permusuhan, maka apabila anak-anak ini kemudian jatuh ke pihak lawan, mereka harus mendapatkan manfaat dari perlindungan istimewa yang diberikan oleh Protokol Tambahan ini, baik mereka menjadi tawanan perang atau tidak. Bagi anak-anak yang ikut serta dalam permusuhan tetapi tidak mendapatkan status khusus, mereka harus, dalam segala keadaan, berdasarkan Pasal 45 ayat (3) Protokol ini, diberikan perlindungan secara umum seperti diatur dalam Pasal 75 (Enny Narwati 2008: 4).

Protokol Tambahan II Tahun 1977 merupakan satu kesatuan Protokol Tambahan I Tahun 1977, hanya saja Protokol Tambahan II Tahun 1977 ini berlaku dalam situasi konflik bersenjata yang tidak bersifat Internasional atau non-Internasional. Perlindungan terhadap anak-anak yang terlibat langsung dalam suatu koflik bersenjata yang bersifat non-Internasional diatur dalam Pasal 4 ayat (3) huruf c, dan d, juga dalam Pasal 6 ayat (4).

Pasal 4 ayat (3) huruf c sudah memberikan ketentuan secara tegas dalam hal pelibatan anak dalam konflik bersenjata, yaitu adanya larangan mutlak yang mencakup partisipasi langsung maupun tidak langsung dalam suatu permusuhan. Tetapi jika dilihat dari batasan usia bagi mereka yang diperbolehkan untuk terlibat dalam suatu permusuhan, kiranya Protokol Tambahan II Tahun 1977 ini memberikan pengaturan yang lebih longgar jika dibandingkan dengan Protokol Tambahan I Pasal 77 ayat (2) yang memberikan pengutamaan mereka yang berusia di bawah 18 tahun (Enny Narwati 2008: 4).

Pasal 4 ayat (3) huruf d memberikan perlindungan secara istimewa bagi anak-anak yang belum mencapai usia 15 tahun tapi mereka ikut secara langsung 
dalam suatu permusuhan apabila mereka tertangkap dan kemudian menjadi tawanan perang.

Protokol Tambahan I Tahun 1977 merupakan penyempurnaan dari Konvensi Jenewa 1949 yang berlaku pada situasi konflik bersenjata yang bersifat Internasional. Pengaturan mengenai perlindungan terhadap anak sebagai akibat terjadinya konflik bersenjata pada dasarnya juga mengacu pada Konvensi Jenewa 1949, hanya saja di dalam Protokol Tambahan I lebih diperluas lagi. Beberapa pasal dalam Protokol Tambahan I Tahun 1977 memberikan pengaturan yang spesifik tentang perlindungan terhadap anak dalam konflik bersenjata, yaitu pasalPasal 8, 52, 70, 74, 75, 76, 94, 119, 127, 132, 136, 140.

Protokol Tambahan II tahun mengatur mengenai pertikaian bersenjata yang tidak bersifat Internasional. Protokol ini memberikan jaminan fundamental terhadap anak-anak dalam konflik bersenjata yang tidak bersifat Internasional. Jaminan tersebut meliputi hak atas perawatan dan bantuan, jaminan dalam bidang pendidikan, termasuk pendidikan agama dan kesusilaan, penyatuan kembali keluarga yang terpisah.

\section{Bentuk perlindungan hukum yang diberikan terhadap anak yang ditangkap oleh militer asing di negara konflik}

Hukum Humaniter Internasional belum mengatur tentang status enemy combatant di dalam sebuah konflik bersenjata. Istilah unlawful combatant, seperti halnya enemy combatant, tidak didefinisikan secara langsung dalam perjanjian Internasional dalam Hukum Humaniter Internasional. Penggunaan istilah tersebut sudah lama digunakan baik dalam literatur hukum, dikalangan militer, dan dalam kasus-kasus hukum.

Unlawful combatant dipahami sebagai sebuah istilah untuk
menggambarkan orang-orang yang mengambil bagian langsung dalam permusuhan padahal mereka tidak memiliki hak untuk turut dalam permusuhan. Sehingga mereka tidak dapat diklasifikasikan sebagai tawanan perang ketika mereka jatuh ke tangan musuh. Unlawful combatant tidak dilindungi dalam Konvensi Jenewa I-III, tidak diperlakukan dan dilindungi layaknya seorang tawanan perang. Pada dasarnya unlawful combatant tidak memiliki hak untuk ikut 
berpartisipasi dalam konflik bersenjata yang terjadi, karena mereka bukanlah pasukan militer. Namun, unlawful combatant tetap mendapatkan perlindungan dalam Hukum Humaniter Internasional (Nickita Sumantri 2011: 7).

Penangkapan terhadap anak-anak tidak bisa disamakan dengan penangkapan unlawful combatant, melainkan penangkapan terhadap penduduk sipil yang tidak ikut serta dalam permusuhan (Nickita Sumantri 2011: 8). Salah satu kategori orang yang dapat disebut sebagai unlawful combatant adalah penduduk sipil yang tidak memiliki hak untuk turut serta mengambil bagian dalam konflik bersenjata tetapi mereka melakukannya.

Pasal 5 dari Konvensi Jenewa IV, dinyatakan bahwa penduduk sipil yang dicurigai atau terlibat dalam kegiatan permusuhan dengan keamanan negara atau suatu kegiatan pendudukan dapat ditangkap. Pada Commentary of Geneva Convention IV dijelaskan bahwa frasa tersebut berasal dari bahasa Perancis yaitu "d'une suspicion légitime" artinya adalah harus ada kecurigaan yang pasti, atau dalam bahasa Inggrisnya, the suspicion must be a definite one.

Meskipun belum jelas bagaimana suatu alasan kecurigaan itu benar-benar sesuai dengan Hukum Humaniter Internasional, pasal ini dianggap dapat memperbolehkan pihak-pihak yang diduga akan mengancam keamanan negara dapat ditangkap. Pasal 27 Konvensi Jenewa IV juga dianggap mengizinkan penangkapan penduduk sipil apabila mereka dianggap mengancam keamanan negara. Pasal 27 Konvensi Jenewa IV menyatakan bahwa:

"Protected persons are entitled, in all circumstances, to respect for their persons, their honour, their family rights, their religious convictions and practices, and their manners and customs. They shall at all times be humanely treated, and shall be protected especially against all acts of violence or threats thereof and against insults and public curiosity. Women shall be especially protected against any attack on their honour, in particular against rape, enforced prostitution, or any form of indecent assault. Without prejudice to the provisions relating to their state of health, age and sex, all protected persons shall be treated with the same consideration by the Party to the conflict in whose power they are, without any adverse distinction based, in particular, on race, religion or political opinion. However, the Parties to the conflict may take such measures of control and security in regard to protected persons as may be necessary as a result of the war." 
Paragraf terakhir pasal tersebut menjelaskan bahwa pihak-pihak dalam konflik dapat mengambil langkah yang diperlukan dalam hal pengamanan, terhadap orang-orang yang dilindungi menurut konvensi ini, selama hal tersebut diperlukan karena adanya perang yang terjadi.

Pada contoh kasus penangkapan anak-anak Afghanistan oleh Amerika Serikat sebagai enemy combatant, maka bentuk-bentuk perlindungan yang harus diberikan kepada anak-anak yang ditangkap oleh Amerika Serikat sebagai enemy combatant sebagai berikut (Nickita Sumantri 2011: 8):

a. Anak-anak harus diperlakukan secara manusiawi

Pasal 3 Konvensi Jenewa berisi antara lain non-kombatan, termasuk penduduk sipil harus diperlakukan secara manusiawi, tanpa pembedaan yang merugikan yang didasarkan atas ras, warna kulit, agama atau kepercayaan, jenis kelamin, kelahiran atau kekayaan, atau kriteria lain yang serupa. Pasal 37 poin a ICRC juga memberikan perlindungan terhadap anak-anak agar diperlakukan secara manusiawi.

Anak-anak yang ditangkap dan ditahan oleh pihak Amerika Serikat sebagai enemy combatant harus tetap diberikan perlakuan yang manusiawi sesuai dengan ketentuan Pasal 3 dan Pasal 37 poin a tersebut. Anak-anak termasuk golongan penduduk sipil dan walaupun mereka ditahan mereka harus tetap diperlakukan sebagaimana penduduk sipil seharusnya diperlakukan.

b. Anak-anak harus diperlakukan secara khusus

Pasal 76 Konvensi Jenewa IV memberikan perlindungan terhadap penduduk sipil yang ditangkap dan ditahan oleh pihak lawan. Paragraf 5 pasal tersebut dijelaskan bahwa anak-anak di bawah umur harus diberikan perlakuan yang khusus. Anak-anak di bawah umur tidak bisa diberikan perlakuan seperti halnya orang dewasa yang menjadi tahanan. Anak-anak Afghanistan yang ditahan di dalam penjara militer oleh Amerika Serikat ini harus tetap mendapatkan perlindungan selayaknya penduduk sipil. Mereka harus diperlakukan dengan khusus karena anak-anak memiliki kebutuhan yang berbeda dengan orang dewasa.

Selain itu, anak-anak juga memiliki hak untuk mendapatkan kunjungan dari delegasi International Committee of the Red Cross atau ICRC. Kunjungan 
yang dilakukan delegasi ICRC tersebut merupakan kegiatan humaniter yang sangat penting. Delegasi ICRC akan memastikan apakah pihak yang ditahan, dalam kasus ini adalah anak-anak, mendapatkan perlakuan sesuai dengan hukum yang berlaku. Delegasi tersebut juga memiliki tugas untuk memastikan apakah anak-anak yang ditahan tetap mendapatkan hak-haknya dan memastikan bahwa ketentuan-ketentuan dari Konvensi Jenewa tetap dilakukan.

Amerika Serikat telah melakukan kewajibannya dengan baik. Amerika Serikat telah memberikan akses terhadap delegasi ICRC untuk masuk dan mengunjungi tempat penahanan anak-anak Afghanistan tersebut di Afghanistan. Delegasi ICRC tersebut juga melaksanakan tugasnya dengan baik. Mereka membantu dan memfasilitasi para tahanan anak-anak untuk berhubungan dengan keluarganya menggunakan surat dan telepon. Delegasi ICRC juga memberikan bantuan terhadap keluarga tahanan untuk dapat memiliki akses masuk untuk mengunjungi anak atau kerabatnya di tempat mereka ditahan. Dalam kasus ini, The Afghanistan Independent Human Rights Commission juga memiliki akses untuk mengunjungi tempat penahanan anak-anak yang ditangkap.

UNICEF belum diberikan akses untuk mengunjungi tempat penahanan anak-anak yang ditangkap. Dalam laporan terhadap UN's Committee on the Rights of the Child yang ditulis Amerika Serikat atas isu yang menyangkut kasus penangkapan anak Afghanistan, Amerika Serikat tidak memberikan keterangan apakah UNICEF atau badan independen lain memiliki akses terhadap anak-anak yang ditangkap. Hanya dikatakan bahwa ICRC, melalui delegasinya, dan The Afghanistan Independent Human Rights Commission lah yang sampai saat ini memiliki akses terhadap anak-anak yang ditangkap di tempat penahanan mereka.

UNICEF, sebagai lembaga PBB yang menangani masalah anak, seharusnya mendapatkan akses menuju anak-anak tersebut. Sehingga, mereka dapat memantau bagaimana kondisi anak-anak tersebut di dalam penjara militer tempat mereka ditahan. Sayangnya, Amerika Serikat tidak memberikan pernyataan terkait akses UNICEF terhadap anak-anak itu. Selain itu Protokol Tambahan I juga memberikan perlindungan terhadap anak-anak yang ditangkap sebagai enemy combatant oleh Amerika Serikat. 
Anak-anak adalah obyek yang harus diperlakukan dengan penghormatan dan diberikan perlindungan yang khusus. Pasal tersebut menyatakan bahwa anak yang jatuh ke tangan musuh, walaupun mereka bukanlah tawanan perang, tetap mendapatkan perlindungan dan hak-hak sesuai dengan ketentuan pasal ini. Hal ini berarti, anak-anak yang ditangkap sebagai enemy combatant ini masih dilindungi secara penuh oleh ketentuan dalam Protokol Tambahan I ini tanpa terkecuali.

c. Anak-anak harus mendapatkan bantuan hukum

Pasal 37 huruf b CRC menyatakan, bahwa sesungguhnya tidak seorang anak pun dapat dirampas kebebasannya secara melawan hukum atau sewenangwenang. Penangkapan, penahanan atau pemenjaraan seorang anak harus sesuai dengan hukum dan harus digunakan hanya sebagai upaya terakhir dan untuk jangka waktu terpendek. Penangkapan mereka pun tidak dibenarkan oleh hukum humaniter internasional. Seharusnya, anak-anak tersebut mendapatkan bantuan hukum agar dapat menyampaikan keluh kesahnya dan diupayakan untuk dikeluarkan dari penjara tempat mereka ditahan.

ICRC menyatakan bahwa setiap anak yang dirampas kebebasannya, hal ini juga termasuk penangkapan anak-anak Afghanistan oleh Amerika Serikat sebagai enemy combatant, berhak untuk meminta akses ke hukum dan bantuan lainnya. Anak-anak tersebut juga memiliki hak untuk mempertanyakan legalitas perampasan kebebasannya sebelum pengadilan.

Amerika Serikat menyatakan, bahwa bantuan hukum tidak diberikan kepada anak-anak yang ditahan tersebut karena sifat penahanan mereka bukanlah karena mereka telah melakukan suatu kejahatan melainkan untuk mencegah kembalinya kombatan ke medan perang. Dengan kata lain sifat penahanan mereka adalah preventif. Namun, Amerika Serikat menyatakan, bahwa ada banyak proses yang dapat memastikan jika anak-anak tersebut ditahan secara sah dan hanya akan ditahan selama waktu yang diperlukan, termasuk sidang administrasi periodik yang memungkinkan tahanan untuk menantang penahanannya. Pada penjara tempat anak-anak tersebut ditahan, tahanan berhak untuk menghadiri bagian tersebut, bersaksi, memanggil saksi-saksi, memberikan pertanyaan terhadap pemerintah, dan informasi dokumenter. Dalam hal ini, anak-anak tersebut akan 
didampingi dengan wakil pribadi yang melakukan advokasi atas nama anak-anak tersebut.

Walaupun begitu, penangkapan anak-anak Afghanistan tersebut tidak seharusnya dilakukan karena tidak sesuai dengan ketentuan-ketentuan dalam hukum Humaniter Internasional. Seharusnya tetap ada bantuan hukum, baik itu dari Afghanistan maupun dari organisasi independent, yang memberikan bantuan hukum terhadap anak-anak tersebut agar mereka segera dibebaskan dan medapatkan kembali hak-haknya.

d. Anak-anak harus mendapatkan akses terhadap hak-hak mereka

Hak-hak yang dimiliki oleh anak-anak dilindungi oleh CRC. Hak-hak yang dimiliki oleh anak, antara lain hak untuk hidup, hak agar nama dan kebangsaannya dicatat secara sah, hak untuk mengetahui orang tua mereka dan dilindungi oleh mereka, hak untuk mendapatkan pendidikan, hak untuk bermain dan beraktivitas di waktu luang mereka, dan lain-lain.

Walaupun anak-anak sedang ditangkap dan ditahan oleh suatu pihak, hal tersebut bukan berarti bahwa anak-anak tersebut dapat kehilangan hak-hak mereka. Hal tersebut juga berlaku terhadap anak-anak Afghanistan. Mereka tetap memiliki hak untuk menjalani dan menikmati hak-hak mereka. Amerika Serikat, sebagai pihak yang menangkap mereka, juga memiliki kewajiban untuk tetap memberikan akses pada anak-anak tersebut untuk melakukan hak-hak nya.

Penangkapan anak-anak Afghanistan oleh Amerika Serikat merupakan suatu hal yang bertentangan dengan hukum humaniter internasional. Penangkapan tersebut juga termasuk kegiatan yang merebut kebebasan anak. Perlindungan terhadap mereka harus tetap diberikan baik dalam sisi hukum humaniter internasional maupun hak asasi manusia. Karena anak-anak tersebut adalah penduduk sipil dan penduduk sipil harus dilindungi oleh hukum humaniter internasional. Mereka juga merupakan generasi penerus bangsa dan mereka memiliki hak-hak yang harus dilindungi. 


\section{Simpulan dan Saran}

\section{Simpulan}

Berdasarkan hasil pembahasan sebelumnya, maka kesimpulan dari penelitian ini adalah bahwa ketentuan hukum yang mengatur tentang perlindungan anak antara lain: (a) Konvensi Hak Anak dan Protokol Tambahan Konvensi Hak Anak; (b) Konvensi Jenewa Tahun 1949, Konvensi Jenewa III; dan (c) Protokol Tambahan II Konvensi Jenewa.

Bentuk-bentuk perlindungan yang dilakukan kepada anak-anak yang ditangkap militer asing di negara konflik adalah: (a) anak-anak yang ditangkap atau ditahan harus diperlakukan secara manusiawi sesuai dengan pasal 3 dan 37 point a; (b) anak-anak yang ditangkap harus diperlakukan secara khusus, karena anak-anak memiliki kebutuhan yang berbeda dengan orang dewasa; (c) anak-anak harus mendapatkan bantuan hukum, memiliki hak untuk mempertanyakan legalitas perampasan kebebasannya sebelum pengadilan. mereka akan didampingi wakil pribadi yang melakukan advokasi, dan (d) anak-anak harus mendapatkan akses terhadap hak-hak mereka.

\section{Saran}

Untuk mengatasi permasalahan tersebut, semua pihak harus memberikan perlindungan kepada anak-anak di negara konflik. Anak-anak yang ditangkap oleh militer asing harus diperlakukan secara khusus dan ketentuan-ketentuan mengenai perlindungan anak harus dilaksanakan. 


\section{DAFTAR PUSTAKA}

\section{Buku:}

Maulana. Hasan. 2000. Advokasi dan Hukum Perlindungan Anak, Jakarta: Grasindo.

ICRC. 1979. Kenali ICRC, Bandung: Delegasi Regional ICRC.

ICRC. 2009. ABC Hukum Humaniter Internasional, Jakarta: Institusi Badan Pembinaan Hukum Nasional.

Mochtar Kusumaatmadja. 2002. Konvensi-konvensi Palang Merah Tahun 1949 mengenai Perlindungan Korban Perang, Bandung: Binacipta.

Rina Rusman. 2010, Hukum Humaniter Internasional dalam Studi Hubungan Internasional, Jakarta: Rajawali Pers.

Waluyadi. 2008. Hukum Perlindungan Anak, Bandung: Mandar Maju.

\section{Hasil Penelitian dan Artikel:}

Adwani. 2012. "Perlindungan Terhadap Orang-orang dalam Daerah Konflik Bersenjata Menurut Hukum Humaniter Internasional", Artikel, Aceh: Fakultas Hukum UNSYIAH.

Agus Prakoso. 2007. "Perlindungan Hukum terhadap Anak dalam Konflik Bersenjata Internasional antara Israel dan Libanon", Skripsi, Surakarta: Program Studi Ilmu Hukum Universitas Sebelas Maret.

Dani Aulia. "Peran Lembaga Khusus PBB", https://daninformen.wordpress. com/2013/12/17/tugas-lembaga-khusus-pbb/, diakses tanggal 1 Desember 2014.

Desi Winarti. "Peranan UNICEF dalam Menangani Masalah Tentara Anak di Afrika Tengah Tahun 2007-2012", Artikel.

Dicky Julanda. "ICRC”, http://saldicky.blogspot.com/2012/06/icrc-internationalcommittee-of-red.html, diakses tanggal 1 Desember 2014.

Enny Narwati (et. al). 2008. "Perlindungan Hukum terhadap Anak dalam Konflik Bersenjata", Artikel.

LBH Jawa Tengah. "Sekilas tentang Hukum Humaniter Internasional”, melalui http://lbhjawatengah.com/article/126169/sekilas-tentang-hukumhumaniter-internasional.html, diakses tanggal 13 Januari 2015. 
Lovetya. "Perlindungan Anak dalam Konflik Bersenjata ditinjau dari Segi Hukum Humaniter Internasional", melalui http://lovetya.wordpress.com/2008/ 12/12/perlindungan-anak-dalam konflik-bersenjata, diakses tanggal 1 Desember 2014.

Nickita Sumantri. 2011. "Penangkapan Anak-anak dalam Konflik Bersenjata di Afghanistan dengan Tuduhan Sebagai Enemy Combatant (Suatu Kajian dari Perspektif Hukum Humaniter Internasional", Artikel, Malang: Fakultas Hukum Universitas Brawijaya.

Rentha, P. N. 2009. "Penerapan Hukum Internasional dalam Menyelesaikan Konflik Internasional Israel dan Palestina, Skripsi, Medan: Program Studi Ilmu Hukum Program Sarjana Fakultas Hukum Universitas Sumatera Utara.

Shadrinaningrum. 2010. "Status dan Perkembangan Peran ICRC Sebagai Subjek Hukum Internasional”, Skipsi, Medan: Program Studi Ilmu Hukum Universitas Sumatera Utara. 


\section{BIODATA PENULIS}

$\begin{array}{ll}\text { Nama } & \text { : Faisal Riza } \\ \text { Pekerjaan } & : \text { Dosen Fakultas Hukum Universitas Muhammadiyah Sumatera } \\ & \text { Utara } \\ \text { Jabatan } & : \text { Asisten Ahli } \\ \text { Nomor HP } & : \text { 081265116496 } \\ \text { E-mail } & : \text { faisalrizaadv@gmail.com } \\ \text { Alamat Kantor } & : \text { Jl. Kapten Muchtar Basri No. 3, Medan }\end{array}$ 